Research Article

Open Access

\title{
Thermodynamic analysis of Experimental Sorption isotherms of dietetic Chhana Kheer
}

\author{
Anuj Kumar Gautam 1 , Tanweer Alam ${ }^{2 *}$, Aastha Bhardwaj ${ }^{3}$ and Alok Jha ${ }^{4}$ \\ IScientist (Animal Science), Krishi Vigyan Kendra, Jalaun, UP-285001, India \\ ${ }^{2} J$ oint Director \& Regional Head, Indian Institute of Packaging, New Delhi-110092, India \\ ${ }^{3}$ Lecturer, Department of Food Technology, Jamia Hamdard, New Delhi-110062, India \\ ${ }^{4}$ Ex-South Asia Head, International Livestock Research Institute, India
}

\section{Article Info}

\section{*Corresponding author:}

Tanweer Alam

Joint Director \& Regional Head

Indian Institute of Packaging

New Delhi- 110092

India

Tel: +91-9310601300

E-mail: amtanweer@rediffmail.com

\section{Received: August 4, 2018}

Accepted: August 29, 2018

Published: September 3, 2018

Citation: Gautam AK, Alam T, Bhardwaj A, Jha A. Thermodynamic analysis of Experimental Sorption isotherms of dietetic Chhana Kheer. Madridge J Food Technol. 2018; 3(2): 126-131. doi: $10.18689 / \mathrm{mjft}-1000119$

Copyright: ๑ 2018 The Author(s). This work is licensed under a Creative Commons Attribution 4.0 International License, which permits unrestricted use, distribution, and reproduction in any medium, provided the original work is properly cited.

Published by Madridge Publishers

\begin{abstract}
The equilibrium moisture contents of dietetic chhana kheer were determined using the static gravimetric method at 10,25 and $37^{\circ} \mathrm{C}$ over a range of water activity from 0.113 to 0.868 . Out of the six sorption models fitted to the sorption data, Modified Mizrahi model for 10 and $25^{\circ} \mathrm{C}$ and Guggenheim-Anderson-de Boer (GAB) model for $37^{\circ} \mathrm{C}$, was described as the best to determine water activity relationship of dietetic chhana kheer having the highest coefficient of determination $\left(R^{2}\right)$ and the lowest root mean square error (RMSE). The isosteric heat of sorption which was calculated from Clausius-Clapeyron type equation was observed to increase with decrease in the moisture content. Also, it was found to come closer to the heat of vaporization of free water above $25.95 \mathrm{~kJ} / \mathrm{kg}$.
\end{abstract}

Keywords: Water activity; Chhana kheer; Thermodynamics; Isosteric heat of sorption; Heat of vaporization.

\section{Introduction}

Kheer is a heat desiccated, cereal-based sweetened and concentrated milk product, commonly used as a dessert. It is usually made by boiling milk along with rice and sugar to get a semi-solid consistency. Its thick consistency is the result of the concentration of milk and simultaneous oozing out of rice starch into milk. Kheer is a product that is prepared on all social rituals and festive occasions and finds mention in ancient vedic and religious texts [1]. In South Asia, Kheer is prepared and eaten on almost every festival. It is also eaten among the Muslim community of North India, and also in Pakistan, Iran and Afghanistan. It is deeply rooted as a traditional dairy delicacy in social lives, cultural festivals and religious ceremonies in Indian sub-continent, which is now being liked and accepted in various other countries also. In chhana kheer, instead of using rice, chhana (a product obtained by heat-acid coagulation of milk) is used. Large scale manufacturing of chhana kheer has been difficult due its very poor shelf life and lack of mechanized production and packaging technologies. High moisture content of chhana kheer results into spoilage of the product within two weeks even at refrigeration temperature.

Moisture sorption isotherms show the relationship between water activity and moisture content of a food sample at a specific temperature as well as pressure [2] These isotherms are an important tool to assess and predict the shelf-life stability, storage conditions and packaging problems encountered by foods during storage [3]. Water activity plays a vital role in spoilage of foods, determining the shelf-stability and deteriorative mechanisms in food systems. Several scientists have reported and 
published moisture sorption isotherms of various dairy products such as kalakand [4], banana shrikhand [5], bottle gourd burfi [6], cham-cham [7], sandesh powder [8], mexican mennonite-style cheese [9] and dietetic rabri [10] at various temperatures.

Proteins and carbohydrates, which comprise of majority of non fat milk solids, are primarily responsible for sorption properties of milk and milk products. Water is the principle component present in milk which serves dual purposes namely, as a solvent as well as a plasticizer for proteins and carbohydrates. Sorption isotherms of several foods have been well narrated by employing appropriate models proposed by Halsey and Oswin [11,12], which have been observed to be the most suitable two parameter models for these studies. Also, Caurie [13] proposed a model which could help to analyze different properties of sorbed water. The COST-90 study by Wolf et al. [14] revealed that the three parameter models such as Guggenheim-Anderson-de Boer (GAB) could be used to describe most food isotherms over a wide water activity range as stated by Bizot [15]. Modified Mizrahi model is another three parameter model, which fits the sorption isotherms of some foods given by Mizrahi and Karel [16].

In almost all milk sweets, presence of sugar imposes restriction on its consumption due to health reasons. Therefore, a process for manufacturing dietetic chhana kheer based on milk fat, aspartame, acesulfame- $K$ and sucralose as main ingredients was optimized. Low calorie sweeteners such as aspartame, acesulfame- $\mathrm{K}$ and sucralose were used as a replacement for sucrose in the manufacture of chhana kheer [17]. The objective of the present study was, therefore, to obtain experimental data on moisture sorption isotherms of dietetic chhana kheer at different temperatures $\left(10,25\right.$ and $37^{\circ} \mathrm{C}$ ) so as to analyze them with different sorption models and generate information on moisture sorption characteristics which could help in developing a process for the manufacturing and storage of chhana kheer.

\section{Materials and Methods}

\section{Materials}

Cow milk was obtained from the Dairy Farm of Banaras Hindu University, Varanasi, India. Artificial sweeteners (Nutrasweet Co., USA) were procured from Kawarlal \& Company, Chennai, India.

\section{Preparation of chhana kheer}

For preparation of chhana kheer, an intermediate base material called as chhana was prepared from cow milk having 40 $\mathrm{g} / \mathrm{L}$ fat. This milk was heated to $85^{\circ} \mathrm{C}$ without any holding time then cooled to $75^{\circ} \mathrm{C}$. A solution of citric acid $(2 \mathrm{~g}$ citric acid diluted to $100 \mathrm{~mL}$ distilled water) was added for coagulation. The coagulated mass was then tied in a muslin cloth of appropriate size and hanged for $30 \mathrm{~min}$ for drainage of whey. The coagulated mass was further washed for 15-20 min and was finally added to milk along with sweeteners. A detailed process diagram for the manufacture of dietetic chhana kheer is presented in figure 1. The dietetic chhana kheer had $53.80 \mathrm{~g} / \mathrm{L}$ moisture, $8.20 \mathrm{~g} / \mathrm{L}$ fat, $10.58 \mathrm{~g} / \mathrm{L}$ protein and $1.69 \mathrm{~g} / \mathrm{L}$ ash.

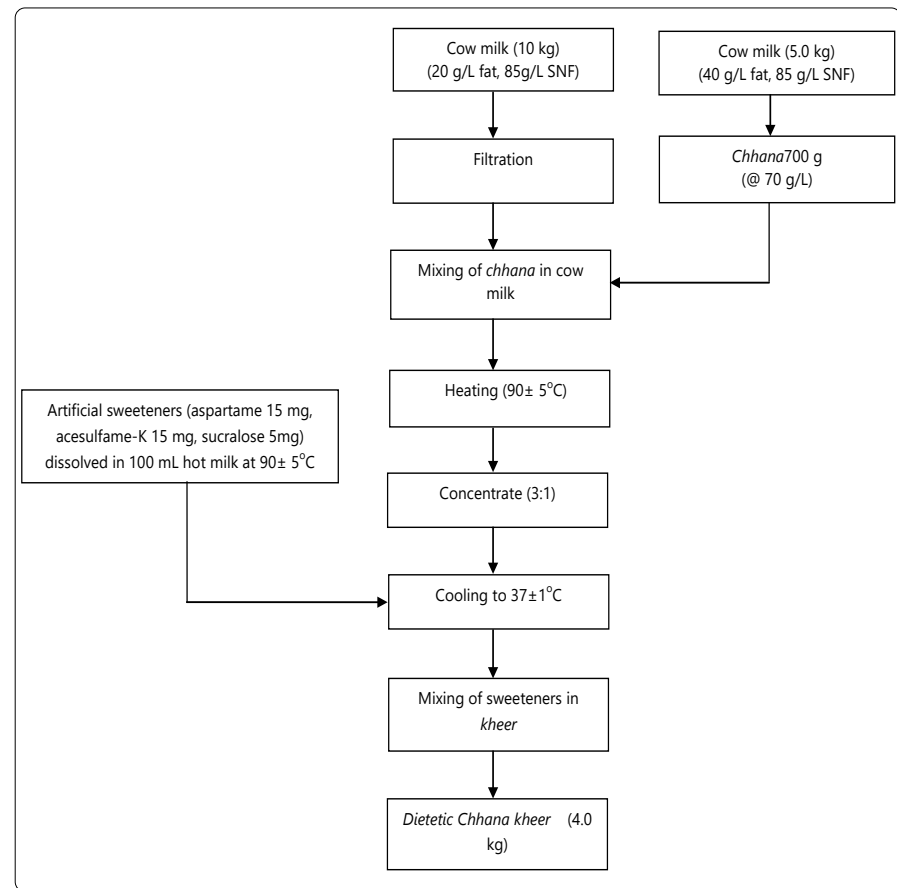

Figure 1. Process diagram for the manufacture of dietetic chhana kheer along with mass balance.

\section{Sorption studies}

Saturated salt solutions of lithium chloride, potassium acetate, potassium carbonate, magnesium nitrate, potassium iodide, sodium chloride, ammonium sulphate and potassium chloride were used to obtain water activities $\left(a_{w}\right)$ values of $0.113,0.234,0.431,0.574,0.721,0.757,0.821$ and 0.868 , respectively, reported [18]. These saturated solutions were placed in air tight, wide mouth glass jars. Approximately $1 \mathrm{~g}$ of sample was weighed into a glass beaker placed on glass bead support inside the glass jar. The glass beakers were equilibrated for three days with the humid atmosphere before placing the sample. Then the moisture sorption characteristics were studied at 10,25 and $37^{\circ} \mathrm{C}\left( \pm 2^{\circ} \mathrm{C}\right)$ by placing the sample containing glass jars in incubators for equilibration. The samples in bottles were weighed at a regular interval of 3 days till a constant weight was attained. Equilibrium was considered to have accomplished when the weight difference between two successive weighing was less than $1 \mathrm{mg}$. Experiment was conducted in three replications of different samples at each relative humidity and temperature conditions. After the equilibrium has been attained, the moisture content of the samples were determined by gravimetric method and was expressed in gram per litre $(\mathrm{g} / \mathrm{L})$. These equilibrium moisture contents were then plotted against relative humidities or water activities to obtain moisture sorption isotherms (adsorption, desorption and hysteresis).

\section{Sorption models}

Several models have been reported in the literature to describe sorption isotherms of various foods [19]. In this study, the isotherm models fitted to the data are presented below. The linearized forms of two-parameter models were used for evaluating the best fitted values of model constants using a linear regression programme. 
HALSEY

$$
a_{w}=e^{\left[\frac{-a}{W^{b}}\right]}
$$

OSWIN

$$
W=a\left\{\frac{a_{w}}{\left(1-a_{w}\right)}\right\}^{b}
$$

CAURIE

$$
\ln \frac{1}{W}=\ln \frac{1}{C W_{o}}+\frac{2 C}{W_{o}} \ln \frac{1-a_{w}}{a_{w}}
$$

SMITH

$$
M=a-b \ln \left(1-a_{w}\right)
$$

\section{MODIFIED MIZRAHI}

$$
W=W_{o} \frac{G k a_{w}}{\left(1-k a_{w}\right)\left[1-k a_{w}+G k a_{w}\right]}
$$$$
\mathrm{GAB}
$$$$
W=\frac{a+a_{w}\left(c a_{w}+b\right)}{a_{w}-1}
$$

The GAB model could be rearranged into a second degree polynomial equation as given below:

$$
\frac{a_{w}}{W}=a a_{w}^{2}+b a_{w}+c
$$

where

$$
\begin{aligned}
& a=\frac{k}{W_{o}}\left[\frac{1}{G-1}\right] \\
& b=\frac{1}{W_{o}}\left[1-\frac{2}{G}\right] \\
& c=\frac{1}{W_{o} k G}
\end{aligned}
$$

Where, $a, b$ and $c$ are model constants and significantly depend on type of regression analysis. A nonlinear least square procedure is considered to be the most reliable technique to find out these model constants [20,21]. Therefore, a nonlinear regression analysis of $a_{w} / W v / s a_{w}$ yields a polynomial equation of the second order. The coefficients $a, b$ and $c$ were thus obtained from this polynomial equation and then substituted to obtain $G A B$ constants $W_{o}, G$ and $k$. $W_{0}$ is the moisture content corresponding to saturation of all primary adsorption sites by one water molecule (equivalent to monolayer moisture content in BET theory), $\mathrm{G}$ is the Guggenheim constant and $\mathrm{k}$ is the factor correcting for properties of multilayer molecule with respect to the bulk liquid. Density of bound water is represented by $\mathrm{C}$ in Caurie model and percent bound water or non freezable water is the product of monolayer value $\mathrm{W}_{\mathrm{o}}$ in the model and number of adsorbed monolayers $(\mathrm{N})$. The accuracy of fit was evaluated by calculating the root mean square error (RMSE) and residuals ( $\mathrm{R}^{2}$ ).

\section{Isosteric heat of sorption}

Isosteric heat of sorption is used as an indicator of binding energy of absorbed water by solid particles [22]. Estimation of isosteric heat of sorption data from isotherms at two or more temperatures allows prediction of isotherms at any temperature [23]. The net isosteric heat of sorption provides an estimation of heat required to be removed in excess of latent heat of vaporization of pure water for extracting sorbed water at particular moisture content. Since, sorption data are obtained at different temperatures, it is possible to evaluate the net heat of sorption $\mathrm{q}_{\mathrm{st}}\left(\mathrm{kJ} \cdot \mathrm{mol}^{-1}\right)$ at different moisture contents using the best-fitted isotherm model.

The value of $\mathrm{q}_{\mathrm{st}}\left(\mathrm{kJ}^{\mathrm{mol}} \mathrm{-}^{-1}\right)$ can be calculated using ClausiusClapeyron type equation as given below [24]:

$$
\ln \left(\frac{a_{w 2}}{a_{w 1}}\right)=\frac{1000 q_{s t}}{R}\left(\frac{1}{T_{1}}-\frac{1}{T_{2}}\right)
$$

Where, $a_{w 1}$ and $a_{w 2}$ is the water activity (decimal) at temperatures $T_{1}$ and $T_{2} K$, respectively. $Q_{s t}$ is the net isosteric heat (J.mol-1) of sorption and $\mathrm{R}$ is the universal gas constant (8.31 J.mol-1.K-1). Isosteric heat $\mathrm{Q}_{\text {st }}\left(\mathrm{kJ} . \mathrm{mol}^{-1}\right)$ of sorption is calculated by the following relationship:

$$
Q_{s t}=q_{s t}+\Delta H_{v}
$$

Where, $\Delta \mathrm{H}_{\mathrm{v}}$ is the latent heat $\left(\mathrm{kJ} . \mathrm{mol}^{-1}\right)$ of vaporization of pure

\begin{tabular}{|c|c|c|c|c|c|c|c|}
\hline \multirow{2}{*}{\multicolumn{3}{|c|}{ Isotherm models Temperature $\left({ }^{\circ} \mathrm{C}\right) \mathrm{a}_{\mathrm{w}}{ }^{*}$ range }} & \multicolumn{3}{|c|}{ Model constants } & \multirow{2}{*}{\multicolumn{2}{|c|}{$\mathrm{R}^{2^{\star}} \mathrm{RMSE}^{*}$}} \\
\hline & & & $a^{*}$ & $b^{*}$ & $c^{*}$ & & \\
\hline Halsey: $a_{w}=\exp \left(\frac{-a}{R T} \frac{1}{M^{r}}\right)$ & $\begin{array}{l}10 \\
25 \\
37\end{array}$ & $\begin{array}{l}0.113-0.868 \\
0.113-0.868 \\
0.113-0.868 \\
\end{array}$ & $\begin{array}{c}-0.27 \\
0.44 \\
-0.67 \\
\end{array}$ & $\begin{array}{l}2.44 \\
1.60 \\
1.14 \\
\end{array}$ & $\begin{array}{l}- \\
- \\
-\end{array}$ & $\begin{array}{l}0.98 \\
0.95 \\
0.96\end{array}$ & $\begin{array}{r}9.30 \\
11.77 \\
13.42 \\
\end{array}$ \\
\hline Oswin: $M=a\left(\frac{a_{w}}{1-a_{w}}\right)^{n}$ & $\begin{array}{l}10 \\
25 \\
37 \\
\end{array}$ & $\begin{array}{l}0.234-0.868 \\
0.113-0.868 \\
0.113-0.868 \\
\end{array}$ & $\begin{array}{l}0.19 \\
0.34 \\
0.47 \\
\end{array}$ & $\begin{array}{l}2.57 \\
1.82 \\
1.48 \\
\end{array}$ & $\begin{array}{l}- \\
- \\
-\end{array}$ & $\begin{array}{l}0.96 \\
0.99 \\
0.96\end{array}$ & $\begin{array}{c}14.41 \\
5.54 \\
13.43 \\
\end{array}$ \\
\hline Caurie: $\frac{1}{M}=\frac{1}{C_{c} M_{m}}\left(\frac{1-a_{w}}{a_{w}}\right)^{\left(2 C_{c} / M_{m}\right)}$ & $\begin{array}{l}10 \\
25 \\
37\end{array}$ & $\begin{array}{l}0.234-0.868 \\
0.113-0.868 \\
0.113-0.868\end{array}$ & $\begin{array}{l}0.56 \\
0.34 \\
0.47\end{array}$ & $\begin{array}{l}-2.57 \\
-1.82 \\
-1.48\end{array}$ & $\begin{array}{l}- \\
- \\
-\end{array}$ & $\begin{array}{l}0.96 \\
0.99 \\
0.96\end{array}$ & $\begin{array}{c}14.41 \\
5.54 \\
13.94\end{array}$ \\
\hline $\mathrm{GAB}: \frac{M}{M_{M}}=\frac{C_{g} k a_{w}}{\left(1-k a_{w}\right)\left(1-k a_{w}+C_{g} k a_{w}\right)}$ & $\begin{array}{l}10 \\
25 \\
37\end{array}$ & $\begin{array}{l}0.234-0.868 \\
0.113-0.868 \\
0.113-0.868 \\
\end{array}$ & $\begin{array}{l}3.02 \\
8.58 \\
4.62 \\
\end{array}$ & $\begin{array}{l}4.34 \\
-7.02 \\
-4.44 \\
\end{array}$ & $\begin{array}{l}9.02 \\
1.88 \\
1.10 \\
\end{array}$ & $\begin{array}{l}0.98 \\
0.98 \\
0.96\end{array}$ & $\begin{array}{c}9.50 \\
6.03 \\
13.28 \\
\end{array}$ \\
\hline Modified Mizrahi: $M\left(a_{w}-1\right)=a+b a_{w}+c a_{w}{ }^{2}$ & $\begin{array}{l}10 \\
25 \\
37 \\
\end{array}$ & $\begin{array}{l}0.113-0.868 \\
0.113-0.868 \\
0.113-0.868\end{array}$ & $\begin{array}{l}-0.08 \\
-0.18 \\
-0.33 \\
\end{array}$ & $\begin{array}{l}0.13 \\
0.22 \\
0.34 \\
\end{array}$ & $\begin{array}{l}-0.00 \\
0.02 \\
0.03 \\
\end{array}$ & $\begin{array}{l}0.98 \\
0.90 \\
0.99\end{array}$ & $\begin{array}{c}8.78 \\
4.87 \\
13.60 \\
\end{array}$ \\
\hline Smith: $M=a-b \ln \left(1-a_{w}\right)$ & $\begin{array}{l}10 \\
25 \\
37\end{array}$ & $\begin{array}{l}0.113-0.868 \\
0.113-0.868 \\
0.113-0.868\end{array}$ & $\begin{array}{l}5.26 \\
4.49 \\
4.91\end{array}$ & $\begin{array}{l}8.79 \\
2.91 \\
0.87\end{array}$ & $\begin{array}{l}- \\
- \\
-\end{array}$ & $\begin{array}{l}0.97 \\
0.99 \\
0.96\end{array}$ & $\begin{array}{c}17.82 \\
8.60 \\
14.58\end{array}$ \\
\hline
\end{tabular}
water at the mean value of two temperatures i.e., $23.5^{\circ} \mathrm{C}$ used in the present study.

\section{Results and Discussion Sorption models}

The time to reach equilibrium was $25-30$ days for samples stored at 25 and $37^{\circ} \mathrm{C}$ while $50-60$ days for samples stored at $10^{\circ} \mathrm{C}$ The values of constants $a, b$ and $c$, and their corresponding $R^{\star}, R^{2}$ and RMSE values for both adsorption and desorption processes are shown in tables 1 and 2.

Table 1. Estimated parameters of isotherm equations fitted to the adsorption data of dietetic chhana kheer.

${ }^{*} a_{w}=$ water activity; $a, b, c=$ coefficients obtained from polynomial equation of models; $R^{2}=$ Residuals; RMSE = Root mean square error 
Table 2. Estimated parameters of isotherm equations fitted to the desorption data of dietetic chhana kheer.

\begin{tabular}{|c|c|c|c|c|c|c|}
\hline \multirow{2}{*}{\multicolumn{2}{|c|}{ Isotherm models Temperature $\left({ }^{\circ} \mathrm{C}\right) \mathrm{a}_{w}{ }^{*}$ range }} & \multicolumn{3}{|c|}{ Model constants } & \multirow{2}{*}{\multicolumn{2}{|c|}{$\mathrm{R}^{2^{\star}} \mathrm{RMSE}^{\star}$}} \\
\hline & & $a^{*}$ & $\mathrm{~b}^{\star}$ & $C^{*}$ & & \\
\hline Halsey: $a_{w}=\exp \left(\frac{-a}{R T} \frac{1}{M^{r}}\right)$ & \begin{tabular}{|l|l|}
10 & 0.11 \\
25 & 0.11 \\
37 & 0.11 \\
\end{tabular} & $\begin{array}{l}-0.71 \\
-0.47 \\
-0.55 \\
\end{array}$ & $\begin{array}{l}1.89 \\
1.75 \\
1.50 \\
\end{array}$ & $\begin{array}{l}- \\
- \\
-\end{array}$ & $\begin{array}{l}0.99 \\
0.96 \\
0.97 \\
\end{array}$ & \begin{tabular}{|l|}
7.13 \\
12.13 \\
16.83 \\
\end{tabular} \\
\hline Oswin: $M=a\left(\frac{a_{w}}{1-a_{w}}\right)$ & \begin{tabular}{l|l}
10 & 0.23 \\
25 & 0.11 \\
37 & 0.11
\end{tabular} & $\begin{array}{l}0.49 \\
0.34 \\
0.39\end{array}$ & $\begin{array}{l}2.24 \\
1.98 \\
1.77\end{array}$ & $\begin{array}{l}- \\
- \\
-\end{array}$ & $\begin{array}{l}0.97 \\
0.97 \\
0.95\end{array}$ & $\begin{array}{l}11.50 \\
7.64 \\
11.20\end{array}$ \\
\hline Caurie: $\frac{1}{M}=\frac{1}{C_{c} M_{m}}\left(\frac{1-a_{w}}{a_{w}}\right)^{\left(2 C_{c} / M_{m}\right)}$ & \begin{tabular}{l|l}
10 & $0.234-0.868$ \\
25 & $0.113-0.868$ \\
37 & $0.113-0.868$
\end{tabular} & $\begin{array}{l}0.49 \\
0.34 \\
0.39\end{array}$ & $\begin{array}{l}-2.24 \\
-1.98 \\
-1.77\end{array}$ & $\begin{array}{l}- \\
- \\
-\end{array}$ & $\begin{array}{l}0.97 \\
0.97 \\
0.95\end{array}$ & $\begin{array}{l}11.50 \\
7.62 \\
11.88\end{array}$ \\
\hline GAB: $\frac{M}{M_{M}}=\frac{C_{g} k a_{w}}{\left(1-k a_{w}\right)\left(1-k a_{w}+C_{g} k a_{w}\right)}$ & \begin{tabular}{l|l|}
10 & $0.234-0.868$ \\
25 & $0.113-0.868$ \\
37 & $0.113-0.868$
\end{tabular} & $\begin{array}{l}-0.21 \\
-0.08 \\
-0.11\end{array}$ & $\begin{array}{l}0.21 \\
0.13 \\
0.15\end{array}$ & $\begin{array}{l}0.01 \\
0.02 \\
0.03\end{array}$ & $\begin{array}{l}0.97 \\
0.95 \\
0.96\end{array}$ & $\begin{array}{l}6.89 \\
5.99 \\
7.21\end{array}$ \\
\hline $\begin{array}{l}\text { Modified Mizrahi: } \\
M\left(a_{w}-1\right)=a+b a_{w}+c a_{w}{ }^{2}\end{array}$ & \begin{tabular}{l|l|}
10 & $0.113-0.868$ \\
25 & $0.113-0.868$ \\
37 & $0.113-0.868$ \\
\end{tabular} & \begin{tabular}{|l|}
4.39 \\
12.01 \\
10.92 \\
\end{tabular} & $\begin{array}{l}-4.61 \\
-9.90 \\
-9.66\end{array}$ & $\begin{array}{l}-2.99 \\
-2.03 \\
-1.21\end{array}$ & $\begin{array}{l}0.98 \\
0.95 \\
0.99\end{array}$ & $\begin{array}{l}6.79 \\
4.35 \\
11.25 \\
\end{array}$ \\
\hline Smith: $M=a-b \ln \left(1-a_{w}\right)$ & \begin{tabular}{|l|l}
10 & $0.113-0.868$ \\
25 & $0.113-0.868$ \\
37 & $0.113-0.868$ \\
\end{tabular} & \begin{tabular}{|l|}
11.42 \\
4.73 \\
4.13 \\
\end{tabular} & $\begin{array}{l}1.38 \\
3.82 \\
3.29\end{array}$ & $\begin{array}{l}- \\
- \\
-\end{array}$ & $\begin{array}{l}0.98 \\
0.97 \\
0.96\end{array}$ & $\begin{array}{l}14.81 \\
14.16 \\
9.23\end{array}$ \\
\hline
\end{tabular}

*aw = water activity; a, b, c = coefficients obtained from polynomial equation of models; R2 = Residuals; $\mathrm{RMSE}=$ Root mean square error

From tables 1 and 2, it can be predicted that with an increase in temperature, the sorption curve shifted towards the right. With a progressive increase in the water activity, the equilibrium moisture content reduced as the storage temperature increase from $10^{\circ} \mathrm{C}$ to $37^{\circ} \mathrm{C}$. Sorption curves at $10^{\circ} \mathrm{C}$ were sigmoid in shape (Type-II) while at 25 and $37^{\circ} \mathrm{C}$, they were (Type-III) curves [24]. The sorption isotherm curves at $25^{\circ} \mathrm{C}$ and $37^{\circ} \mathrm{C}$ can be divided into three regions to describe the various properties of sorption. The first region corresponding to water activity values up to 0.6 showed increase in equilibrium moisture content, second region corresponding to water activity range between 0.6 and 0.8 showed a depression in curve at water activity value between 0.70 and 0.75 , and third region for water activity values more than 0.8 showed the increase in equilibrium moisture content. The sorption curves of samples stored at $10^{\circ} \mathrm{C}$ also showed three regions. The first region corresponding to $a_{w} \leq 0.234$, which relates to adsorption of monomolecular film of water, second region which indicates the adsorption of additional layers over this monolayer at $a_{w} 0.234$ 0.757 and third region for $a_{w}>0.76$ corresponding to condensation of water in pores of the product followed by dissolution of soluble materials. The sorption curve of dietetic chhana kheer stored at $10^{\circ} \mathrm{C}$ showed the similar results as reported in dhud churpi and burfi $[25,26]$. The equilibrium moisture content (EMC) of chhana kheer at three storage temperatures for both adsorption and desorption processes are shown in figures 2 and 3.

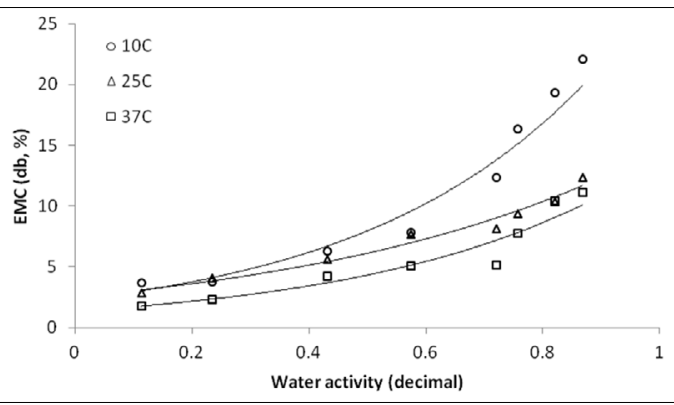

Figure 2. Experimental adsorption isotherms of dietetic chhana kheer.

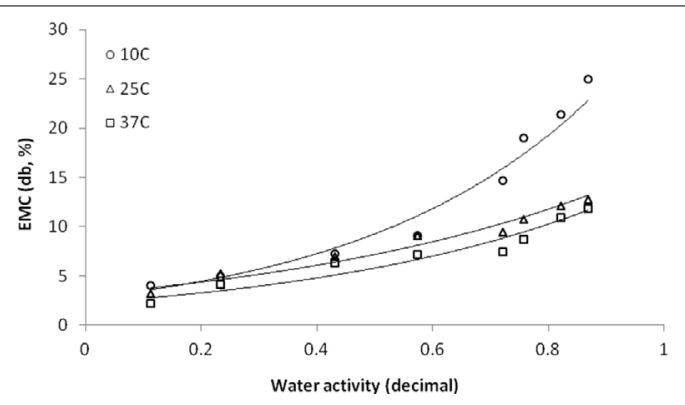

Figure 3. Experimental desorption isotherms of dietetic chhana kheer.

There was a clear hysteresis effect at all the three temperatures, which diminished with decreasing temperatures, as shown in figure 4.

(a)

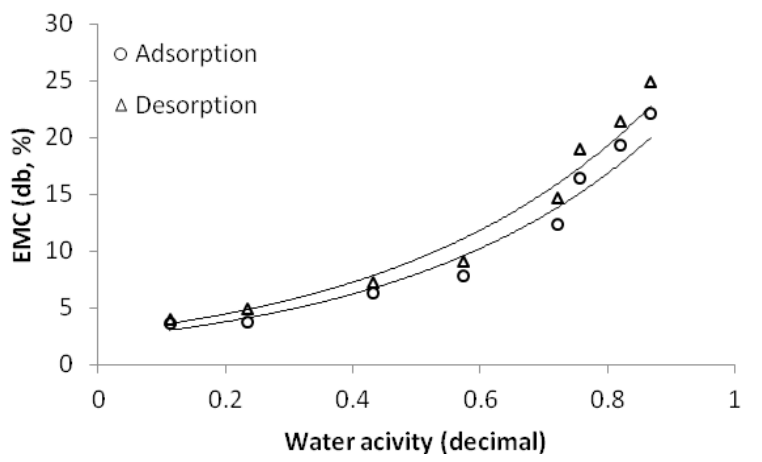

(b)

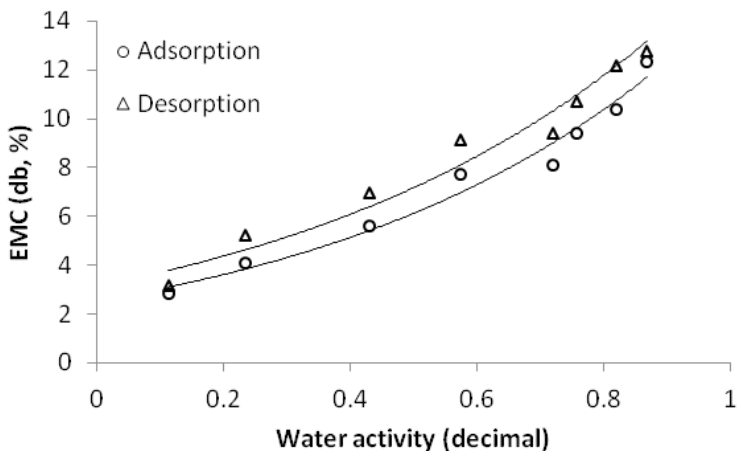

(c)

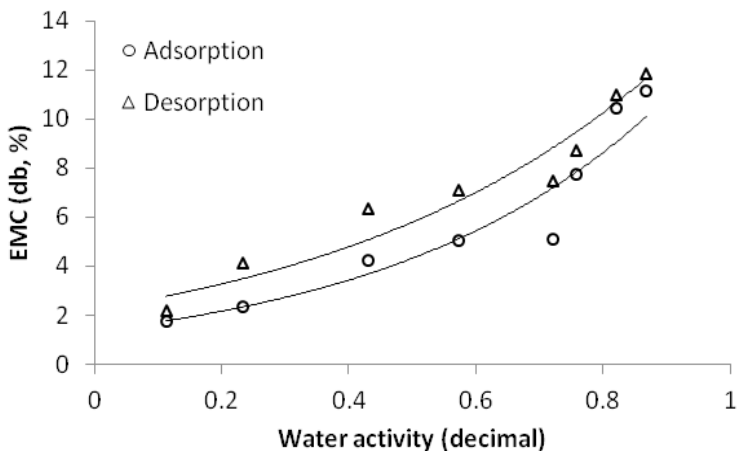

Figure 4. Hysteresis effect of dietetic chhana kheer at (a) $10{ }^{\circ} \mathrm{C}$, (b) $25{ }^{\circ} \mathrm{C}$, and (c) $37^{\circ} \mathrm{C}$.

In dietetic chhana kheer, the major constituent protein was either contributed by chhana or milk used for preparation of chhana kheer. Proteins are the preferred sorption sites at low water activities; the sorption in the low water activity range (around monolayer level) is presumably due to casein. Ahmad $\mathrm{N}$ et al. [27] reported shifting of sorption curve to left side with addition of maltodextrin at higher level (5 or 10\%). The authors explained the role of maltodextrin that at lower water activities, protein being the site for sorption of water in dairy products, the humectants may not be effective in improving the water binding capacity of khoa. At higher water 
activity, carbohydrate being the preferred sorption site could lead to an increased water binding capacity of khoa with the increasing humectants level. Unlike other milk products, the steep acceleration of sorption at higher water activities could not achieved due to lack of sugar in dietetic chhana kheer.

The water binding capacity at higher temperature was low. This may also be contributed to the high protein content of dietetic chhana kheer. Proteins and carbohydrates are known to have more water binding capacity at low temperatures than at high temperatures [28,29]. Berlin E [30] reported the reduction in moisture sorption by whey proteins when the temperature was increased from 24 to $35^{\circ} \mathrm{C}$. At higher temperatures, greater activation of water molecules result in breaking of water molecule from water binding sites thereby lowers the equilibrium moisture content. Similar results were reported by Sahu and Jha [29] in sandesh in which high protein and carbohydrate content caused the reduction in water binding capacity at $30^{\circ} \mathrm{C}$ as compared to $20^{\circ} \mathrm{C}$.

\section{Fitting of sorption isotherms models}

Various models as mentioned in table 1 and 2, for fitting MSIs of chhana kheer were tested. Values in table 1 and 2 indicates that all models curves are in good agreement with experimental EMC for both adsorption and desorption processes. Among the models fitted to the sorption data, Modified Mizrahi model for 10 and $25^{\circ} \mathrm{C}$ and $\mathrm{GAB}$ model for $37^{\circ} \mathrm{C}$ were found good to predict the experimental moisture sorption data and to characterize sorption behavior for the entire range of water activity as exhibited by low RMSE value. All the models showed the lower RMSE values at high storage temperature $\left(37^{\circ} \mathrm{C}\right)$ as well as at refrigerated $\left(10^{\circ} \mathrm{C}\right)$ and ambient temperature $\left(25^{\circ} \mathrm{C}\right)$.

For adsorption process, the Halsey constant varied from 1.14 to 2.44 and -0.67 to -0.27 , Oswin constant varied from 0.19 to 0.47 and 1.48 to 2.57 , Caurie constant varied from 0.34 to 0.56 and -1.48 to $-2.57, \mathrm{GAB}$ constant varied from 3.02 to $8.58,-7.02$ to 4.34 and -9.02 to -1.10 , Modified Mizrahi constant varied from -0.33 to $-0.08,0.13$ to 0.34 and -0.00 to 0.03 and Smith constant varied from 4.49 to 5.26 and 0.87 to 8.79 for dietetic chhana kheer stored at different temperatures. Similarly, for desorption process, the Halsey constant varied from 1.50 to 1.89 and -0.71 to -0.47 , Oswin constant varied from 0.34 to 0.49 and 1.77 to 2.24, Caurie constant varied from 0.34 to 0.49 and -2.24 to -1.77 , GAB constant varied from 0.13 to $0.21,-0.21$ to -0.08 and 0.01 to 0.03, Modified Mizrahi constant varied from 4.39 to $12.01,-9.90$ to -4.61 and -2.99 to -1.21 and Smith constant varied from 4.13 to 11.42 and 1.38 to 3.82 for dietetic chhana kheer stored at different storage temperatures. Modified Mizrahi and GAB model showed the lowest RMSE value and higher $R^{2}$ value. $A$ study showed that GAB model is a useful sorption model for milk proteins and milk powders [31,32]. In another study conducted on chhana based sweets Sandesh and Dudh churpi and Chhana podo $[25,28,29]$. Caurie model was the best fit models at storage temperature of 20 and $30^{\circ} \mathrm{C}$. In the present study, Caurie model showed good agreement, but possess high RMSE value and low $R^{2}$ value as compared to the Modified Mizrahi and GAB models. This variation with other reports may be due to the absence of sugar in dietetic chhana kheer which results in different characteristics of sorption isotherm.
Density of sorbed water $\left(C_{c}\right)$, number of sorbed monolayers $(N)$, per cent bound water $\left(M_{m}\right)$ and surface area of sorbent $(A)$ are calculated using Caurie model for both adsorption and desorption processes, respectively (Table 3). Similar trend has been observed by Kumar et al. [2] and Ghayal et al. [10].

Table 3. Properties of sorbed water in dietetic chhana kheer as calculated by Caurie's model

\begin{tabular}{|c|c|c|c|c|c|c|}
\hline $\begin{array}{c}\text { Sorption } \\
\text { process }\end{array}$ & $\begin{array}{c}\text { Temperature } \\
\left({ }^{\circ} \mathrm{C}\right)\end{array}$ & $\mathrm{M}_{\mathrm{m}}{ }^{*}(\%)$ & $\mathrm{C}_{\mathrm{c}}{ }^{*}(\mathrm{~g} / \mathrm{cm})$ & $\mathrm{N}^{*}$ & $\begin{array}{c}\text { Bound } \\
\text { water }(\%)\end{array}$ & $\mathrm{A}^{*}\left(\mathrm{~m}^{2} / \mathrm{g}\right)$ \\
\hline \multirow{3}{*}{ Desorption } & 10 & 2.24 & 0.49 & 4.57 & 10.24 & 124.42 \\
& 25 & 1.98 & 0.34 & 5.82 & 11.52 & 158.45 \\
& 37 & 1.77 & 0.39 & 4.53 & 8.02 & 123.33 \\
\hline \multirow{3}{*}{ Adsorption } & 10 & 2.57 & 0.56 & 4.52 & 11.61 & 123.06 \\
& 25 & 1.82 & 0.34 & 5.35 & 9.74 & 145.65 \\
& 37 & 1.48 & 0.47 & 3.14 & 4.65 & 85.49 \\
\hline
\end{tabular}

${ }^{*} \mathrm{M}_{\mathrm{m}}=$ per cent bound water; $\mathrm{C}_{\mathrm{c}}=$ density of sorbed water; $\mathrm{N}=$ number of sorbed monolayers; $\mathrm{A}=$ surface area of sorbent

\section{Isosteric heat of sorption}

The data obtained during the study reveals that the isosteric heat of sorption $\mathrm{q}_{\mathrm{st}}$ is a function of EMC during storage (10 and $37^{\circ} \mathrm{C}$ ). The graph showing In $\mathrm{a}_{\mathrm{w}} \mathrm{vs} .1 / \mathrm{T}$ for chhana kheer at different moisture contents interpolated from the experimental data has been shown in figures 5 and 6 . Eq. (12) was used to achieve net isosteric heat (qst) values of adsorption and desorption.

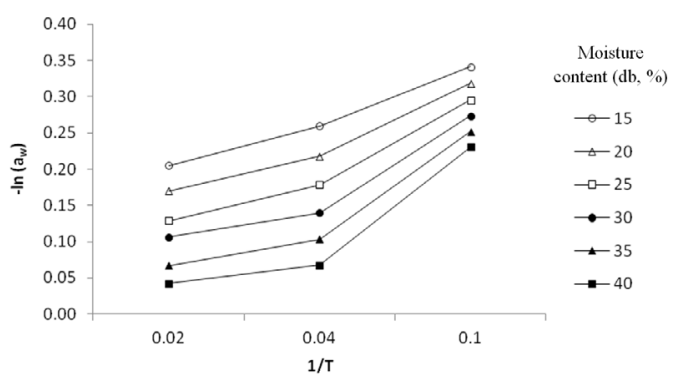

Figure 5. Adsorption isosters of dietetic chhana kheer at different moisture contents.

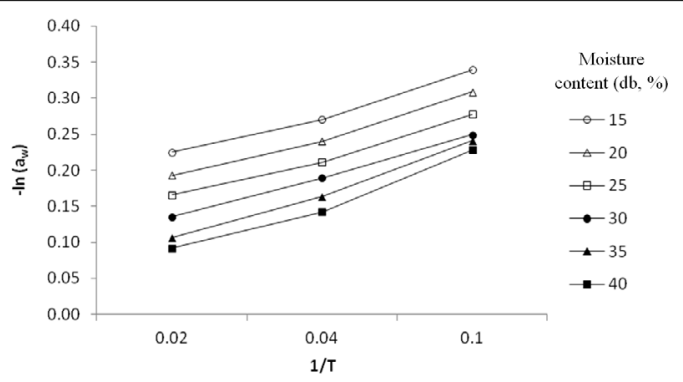

Figure 6. Desorption isosters of dietetic chhana kheer at different moisture contents.

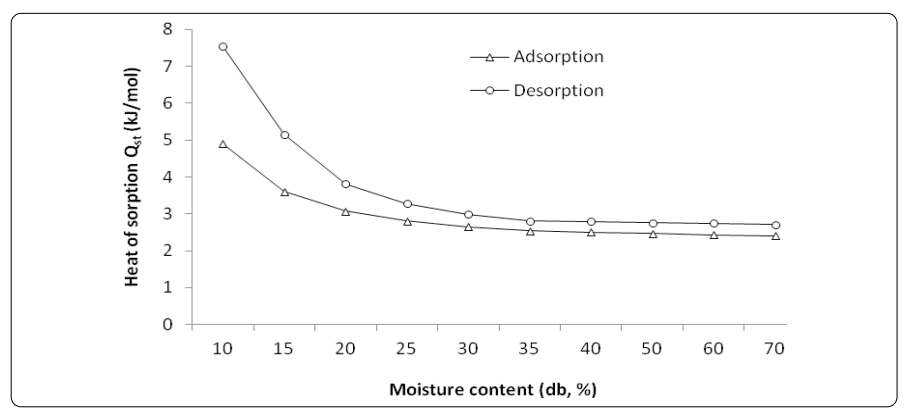

Figure 7. Variation of isosteric heat of sorption with equilibrium moisture content of dietetic chhana kheer (moisture content has been extended to $70 \%$ to show the pattern of both the curves clearly). 
Figure 7 shows variation in net isosteric heat of sorption at different moisture contents. It is inferred from the figure that an increase in the moisture content leads to decrease in the isosteric heat of sorption and it showed no almost change above 24.95 $\mathrm{g} / \mathrm{L}$. Such behavior may be attributed to the fact that sorption phenomenon takes place on the extremely active sites that are associated with elevated interaction energy. Thereafter, these active sites become largely occupied, thus leading to lower interaction energies. Results indicate stronger interactions between the chhana kheer and water vapour at low moisture content, finally leading to large $\mathrm{Q}_{\mathrm{st}}$ values. Similar observations have been made by Deshmukh et al. [3] in kalakand and Puri and Khamrui [7] in cham-cham.

\section{Conclusion}

Moisture sorption isotherms of dietetic chhana kheer showed a Type-II and Type-III curve and the hysteresis loop showed that there is a clear difference in the moisture adsorption and desorption values. Among the six isotherm models tested for their ability to fit the sorption data, Modified Mizrahi and GAB models could be considered best to describe the sorption isotherms at 10 , 25 and $37^{\circ} \mathrm{C}$, respectively. As the temperature increased from 10 to $37^{\circ} \mathrm{C}$, the moisture adsorption and desorption values along with the water binding capacity decreased. These results would be very valuable in optimizing the manufacturing and storage qualities of chhana kheer. The properties of sorbed water were obtained to understand the changes in the sorbed water caused by changes in temperature. The values of isosteric heat of sorption as calculated from Clausius-Clapeyron type equation was found to increase with decreasing moisture content at lower moisture content and approached the value of heat of vaporization of free water above $24.95 \mathrm{~kJ} / \mathrm{kg}$.

\section{Conflict of Interest}

The authors declare that they have no conflict of interest.

\section{References}

1. Aneja RP, Mathur BN, Chandan RC, Banerjee AK. Technology of Indian milk products: handbook on process technology modernization for professionals, entrepreneurs and scientists. Dairy India Yearbook, 2002; 122-125.

2. Kumar AJ, Singh RRB, Patil GR, Patel AA. Effect of temperature on moisture desorption isotherms of kheer. LWT- Food Sci Technol. 2005; 38(3): 303310. doi: 10.1016/j.lwt.2003.10.009

3. Deshmukh G, Birwal P, Patel S, Datir R, Surywanshi A. Sorption Isotherms of Traditional Indian Dairy Products: A Review. J Food Nutr Popul Health. 2017a; 1(3): 25.

4. Deshmukh G, Bhadania AG, Birwal P, Datir R, Patel S, Mishra. Moisture Sorption Hysteresis in Kalakand-At Different Temperatures. Int J Pure App Biosci. 2017b; 5(5): 68-73. doi: 10.18782/2320-7051.2907

5. Amreen QS, Khojare A, Jadhao V. Moisture Sorption Characteristics of Banana Shrikhand. Int J Agri Environ Biotechnol. 2017; 10(5): 589-596. doi: 10.5958/2230-732X.2017.00072.9

6. Amreen QS, Khojare AS, Ingle MP. Sorption Characteristics of Bottle gourd burfi. Acta Scientifica Int J Food Nutri. 2016; 1: 42-53.

7. Puri R, Khamrui K. Effect of Temperature on Sorption Isotherms and Thermodynamics of Intermediate Moisture Category Indian Milk Product Cham-cham. J Food Process Preserv. 2016; 40(5): 999-1009. doi: 10.1111/jfpp. 12680

8. Khojare AS, Hembade AS. Moisture adsorption characteristics of sandesh powder. Indian J Dairy Sci. 2016; 69(3): 259-266.
9. Martinez-Monteagudo Sl, Salais-Fierro F. Moisture sorption isotherms and thermodynamic properties of mexican mennonite-style cheese. J Food Sci Technol. 2014; 51(10): 2393-2403. doi: 10.1007/s13197-012-0765-1

10. Ghayal G, Jha A, Sahu JK, et al. Moisture sorption isotherms of dietetic Rabri at different storage temperatures. Int J Dairy Technol. 2013; 66(4): 587-594. doi: 10.1111/1471-0307.12083

11. Halsey G. Physical adsorption on non-uniform surfaces. J Chem Phys. 1948; 16: 931-937. doi: 10.1063/1.1746689

12. Oswin CR. The kinetics of package life. III. The isotherm. J Chem Technol Biotechnol. 1946; 65(12): 419-423. doi: 10.1002/jctb.5000651216

13. Caurie M. Derivation of full range moisture sorption isotherms. In: Water Activity: Influences on Food Quality, Rockland LB, Stewart GF (Eds.), New York, USA: Academic Press- Elsevier, 1981; 63-87.

14. Wolf W, Speiss WEL, Jung G. Standardization of isotherm measurement In: Properties of Water in Food, Simatos D, Multon JL (Eds.). Netherlands: Marins Nijhoff Publication, 1985; 661-679.

15. Bizot $\mathrm{H}$. Using the GAB model to construct sorption isotherm. In: Physical properties of foods. London, UK: Applied Science Publishers, 1983.

16. Mizrahi $S$, Karel M. Moisture transfer in a packaged production isothermal storage: extrapolating the data to any package-humidity combination and evaluating water sorption isotherms. J Food Process Preserv. 1977; 1: 225-234.

17. Gautam AK, Jha A, Jafri $M$, Kumar A. Optimization of a process for shelfstable dietetic Chhana kheer and changes in physicochemical properties during storage. Int J Dairy Technol. 2014; 67(1): 73-81. doi: 10.1111/14710307.12084

18. Greenspan L. Humidity fixed points of binary saturated aqueous solutions. J Res National Bureau Stand. 1977; 81A: 89-96. doi: 10.6028/jres.081A.011

19. Chirife J, Iglesias HA. Equations for fitting water sorption isotherms of foods: part-I- a review. J Food Technol. 1978; 13(3): 159-174. doi: 10.1111/ j.1365-2621.1978.tb00792.x

20. Schar $W$, Ruegg $M$. The evaluation of $G A B$ constants from water vapour sorption data. LWT-Food Sci Technol. 1985; 18: 225-229.

21. Ramesh MN. Moisture transfer properties of cooked rice during drying. LWTFood Sci Technol. 2003; 36(2): 245-255. doi: 10.1016/S0023-6438(02)00228-1

22. Fasina $\mathrm{O}$, Sokhansanj $\mathrm{S}$, Tyler R. Thermodynamics of moisture sorption in alfalfa pellets. Drying Technol. 1997; 15(5): 1553-1570. doi: 10.1111/1471-0307.12084

23. Labuza TP, Kaanane A, Chen JY. Effect of temperature on the moisture sorption isotherms and water activity shift of two dehydrated foods. $J$ Food Sci. 1985; 50(2): 385-392. doi: 10.1111/j.1365-2621.1985.tb13409.x

24. Brunauer $S$, Deming LS, Teller E. On a theory of Van der Waals adsorption of gases. J Am Chem Soc. 1940; 62(7): 1723-1732. doi: 10.1021/ja01864a025

25. Hossain SA, Pal PK, Sarkar PK, Patil GR. Moisture sorption characteristics of dudh churpi - a traditional milk product in India. Nahrung. 2002; 46(3): 136-140. doi: 10.1002/1521-3803(20020501)

26. Chetana R, Srinivasa PC, Reddy SRY. Moisture sorption characteristics of milk burfi, a traditional Indian sweet, using sugar substitutes. Eur Food ResTechnol. 2005; 220(2): 136-141. doi: 10.1007/s00217-004-1007-1

27. Ahmad N, Singh RRB, Singh AK, Patel AA, Patil GR. Effect of maltodextrin addition on moisture sorption properties of khoa. Int J Dairy Technol. 2008; 61(4): 403-410. doi: 10.1111/j.1471-0307.2008.00427.x

28. Rao KJ, Dhas PHA, Emerald FME, Ghosh BC, Balasubramanyam BV, et al. Moisture sorption characteristics of chhana podo at $5^{\circ} \mathrm{C}$ and $35^{\circ} \mathrm{C}$. $\mathrm{J} \mathrm{Food}$ Eng. 2006; 76: 453-459.

29. Sahu JK, Jha A. Storage stability of sandesh - an Indian milk sweet. Agri Eng Int CIGR J. 2008; 10: 1-12.

30. Berlin E. Hydration of milk proteins. In: Water Activity: Influences on Food Quality. Rockland LB, Stewart GF (Eds.), New York, USA: Academic PressElsevier. 1981; 467-488.

31. Jouppila $\mathrm{K}$, Roos $\mathrm{YH}$. Water sorption and time dependent phenomena of milk powders. J Dairy Sci. 1994; 77(7): 1798-1808. doi: 10.3168/jds.S00220302(94)77121-6

32. Kinsella $J E$, Fox PF. Water sorption by milk proteins. Bulletin of the International Dairy Federation No. 209, Institute of Food Science, Cornell University., Ithaca, New York 14853, USA, 1987; 12-40. 